\title{
American Woodcock Priority Information Needs - A Shared Vision
}

DAVE J. CASE, ${ }^{1}$ DJ Case and Associates, 317 East Jefferson Boulevard, Mishawaka, IN 46545, USA

THOMAS R. COOPER, U.S. Fish and Wildlife Service, Region 3 Migratory Bird Program 5600 American Blvd. West, Suite 99o, Bloomington, MN, USA

In 2006, the Association of Fish and Wildlife Agencies' Migratory Shore and Upland Game Bird Working Group established a Migratory Shore and Upland Game Bird Support Task Force (Task Force). The Task Force was composed of nine representatives of state, federal, and non-governmental organizations. The Task Force was directed to update the research and management needs of the 16 species of migratory shore and upland game birds (Table 1), including the American woodcock (Scolopax minor), and to develop a strategy for funding priority research and management needs for these species. The Strategies included priorities that stakeholders believed would significantly improve the management of Migratory Shore and Upland Game Birds and, thus, represent a significant winnowing of hundreds of potential research and management needs, identified in earlier planning efforts (e.g., Tacha and Braun 1994), to 26. In a time of increased budget scrutiny and justification, these Strategies represent a significant accomplishment by focusing efforts on the most important actions.

\section{Strategy Purpose}

The six Strategies each contain recommendations for obtaining priority information needed to improve habitat and harvest management decisions for the 16 species of North American migratory shore and upland game birds. The Strategies focused on evaluating and improving monitoring efforts, measuring vital rates (survival, reproduction, and recruitment), and evaluating habitat needs during the annual life cycle of these birds. The Strategies were intended to provide guidance for research and management activities, and to increase financial support for the program during the next 5-10 years.

\section{Strategy Development Process}

The Task Force determined that convening groups of species experts would be the most efficient and effective process for developing Strategies. Experts from academia and from state and federal agencies in the United States (U.S.) and Canada participated in the process. More than 90 experts, collectively, collaborated on one or more of the Strategies. Many of these experts were intimately involved with the North American Flyway system of managing migratory game birds. Strategy development included a combination of in-person and online meetings, followed by additional work via email, online meetings, and conference calls. The first Strategy was completed in June 2008 and the final Strategy was completed in February 2011. Twenty-nine American woodcock experts (Appendix A) convened at a workshop held in Bloomington, Minnesota, in August 2009 to begin work on the strategy. The team completed "A Priority Information Needs for American Woodcock: A Funding Strategy" in March 2010 (D.J. Case and Associates 2010).

Priority Information Needs For American Woodcock The workshop resulted in the identification of four priority information needs for American woodcock (in priority order):

1. Develop a demographic-based model for assessing American woodcock population response to harvest and habitat management.

2. Develop communication strategies to increase support for policies and practices that benefit American woodcock and other wildlife of young forests.

3. Improve understanding of migration, breeding, and wintering habitat quality for American woodcock.

4. Improve the American Woodcock Singingground Survey.

1 email: dave@djcase.com 
A full description of the four priorities, including background justifications and estimated costs, is available in D.J. Case and Associates (2010).

The planning team for the 11th American Woodcock Symposium (Symposium) used these priorities to organize the program. They believed that the Symposium offered a convenient and worthwhile forum for stakeholders to share the work they have completed to date on the four priorities identified in 2010. The manuscripts shared in this volume will help inform management efforts for American woodcock for years to come.

\section{Literature Cited}

D.J. Case and Associates (editors). 2010. Priority information needs for American woodcock: a funding strategy. Developed for the Association of Fish and Wildlife Agencies by the Migratory Shore and Upland Game Bird Support Task Force. 15pp. https://www. fws.gov/birds/surveys-and-data/webless-migratory-game-birds/ priority-information-needs.php.

Tacha, T.C. and C.E. Braun (editors). 1994. Migratory shore and upland game bird management in North America. International Association of Fish and Game Agencies, Washington, D.C., USA. 223pp.

Table 1. The 16 species of migratory shore and upland game birds for which priority information needs were identified through convening species-specific task forces to develop a strategy for funding priority research and management needs.

\begin{tabular}{ll}
\hline Common Name & Scientific Name \\
King rail & Rallus elegans \\
Clapper rail & Rallus longirostris \\
Virginia rail & Rallus limicola \\
Sora & Porzana carolina \\
Purple gallinule & Porphyrio martinica \\
Common moorhen & Gallinula chloropus \\
American coot & Fulica americana \\
Sandhill crane & Antigone canadensis \\
Wilson's snipe & Gallinago delicata \\
American woodcock & Scolopax minor \\
Band-tailed pigeon & Patagioenas fasciata \\
Scaly-naped pigeon & Patagioenas squamosa \\
Zenaida dove & Zenaida aurita \\
Mourning dove & Zenaida macroura \\
White-winged dove & Zenaida asiatica \\
\hline
\end{tabular}

Appendix A. 2009 American Woodcock Priority Information Needs Workshop participants

- D.E. Andersen, U.S. Geological Survey

- E.B. Blackman, North Carolina State

- R.J. Blohm, U.S. Fish and Wildlife Service/Migratory Shore and Upland Game Bird Task Force

- D.J. Case, MSUGB Task Force

- T.R. Cooper, U.S. Fish and Wildlife Service

- D.R. Dessecker, Ruffed Grouse Society

- J.P. Dunn, Pennsylvania Game Commission,

- D.A. Eklund, U.S. Forest Service

- T.L. Edwards, U.S. Fish and Wildlife Service

- H.M. Hands, Kansas Department of Wildlife and Parks

- B.F. Harvey, Maryland Department of Natural Resources

- M.R. Houser, Potlatch Corporation

- J.R. Kelley, U.S. Fish and Wildlife Service

- S.T. Kelly, U.S. Fish and Wildlife Service

- D.G. Krementz, U.S. Geological Survey

- M.A. Larson, Minnesota Department of Natural Resources

- D.R. Luukkonen, Michigan Department of Natural Resources

- D.G. McAuley, U.S. Geological Survey

- R.O. Morgenweck, U.S. Fish and Wildlife Service/ Migratory Shore and Upland Game Bird Task Force

- M.W. Olinde, Louisiana Department of Wildlife and Fisheries

- P.M. Ruble, Wildlife Management Institute

- J.R. Sauer, U.S. Geological Survey

- J.H. Schulz, Migratory Shore and Upland Game Bird Task Force

- C.A. Stewart, Michigan Department of Natural Resources

- W.E. Thogmartin, U.S. Geological Survey

- K.Van Horn, Wisconsin Department of Natural Resources

- S.D. Wilds, Retired FWS/Wildlife Management Institute Young Forest Initiative Contractor

- K.A. Wilkins, U.S. Fish and Wildlife Service

- G.S. Zimmerman, U.S. Fish and Wildlife Service 